\title{
An Investigation into the Self-handicapping Behaviors of Undergraduates in Terms of Academic Procrastination, the Locus of Control and Academic Success
}

\author{
Figen $\mathrm{Akça}^{1}$ \\ ${ }^{1}$ Faculty of Education, Uludağ University, Bursa, Turkey \\ Correspondence: Figen Akça, Faculty of Education, Uludağ University, Görükle Kampüsü, Bursa, Turkey. Tel: \\ 90-535-448-4385. E-mail: figen_akca@hotmail.com
}

Received: September 20, 2012

Accepted: October 12, $2012 \quad$ Online Published: November 27, 2012

doi:10.5539/jel.v1n2p288

URL: http://dx.doi.org/10.5539/jel.v1n2p288

\begin{abstract}
The aim of this study was to investigate the relationship between self-handicapping, academic procrastination, the locus of control and academic success. The aim was also to determine whether these variables predicted self-handicapping behavior. The population of the study consisted of 263 undergraduates studying in different departments of the Faculty of Education at Uludağ University. The Self-Handicapping Scale (Akın, 2012), Academic Procrastination Scale (Çakıc1, 2003), and Locus of Control Scale (Dă̆ 1991) were used as data collection tools. Data was analyzed via Pearson correlation analysis and multi linear regression. As a result of the correlation analyses, a positively significant relationship was determined between self-handicapping, the external locus of control and academic procrastination. As a result of the regression analysis, it was concluded that academic procrastination, the locus of control and academic success predicted self-handicapping in terms of their explanation rates, respectively. Educators and psychological counselors discussed this issue and they made suggestions in line with the findings.
\end{abstract}

Keywords: self-handicapping, academic procrastination, locus of control, academic success

\section{Introduction}

Successful teaching practice is significantly related to meeting the cognitive, affective, social and physiological needs of students. Cognitive student characteristics include intelligence and skills, learning type and foreknowledge, cognitive development levels and learning strategies. Affective characteristics are primarily the personality structure, interests, motivation and the locus of control. Epistemological beliefs are social characteristics such as peer relations, moral development levels, racial identity and socio-economic level. Physiological characteristics include such variables as gender, age, sensory perception capacity, and the general state of health (Kuzgun \& Deryakulu, 2004).

Every passing day, new ideas and variables are added to the list of personal differences. Recently, the concept of "self-handicapping", among the cognitive characteristics list, has emerged. Many studies have been conducted concerning the concept of "self-handicapping" in the educational environment. (Beck, Koons \& Milgrim 2000; Brown \& Kimble 2009; Chorba \& Isaacson 2012; Akın, 2012). The concept of self-handicapping was first suggested by Berglas and Jones (1978). They stated that individuals who experienced uncertainty about their required sufficiency to perform any task would try to externalize or legitimate their failures. They described self-handicapping as the choice of an action or a situation which could offer the opportunity for "externalizing failure and internalizing success" (p. 406). Many obstacles which can help impute the reasons of failure to external factors, by decreasing the possibility of success for the individual, will obviously serve the aim of justifying the failure of the individual. In other words, if the individual fails, he/she will externalize the source of failure by imputing the reasons for failure to the obstacles. However, if the individual displays a better performance, he/she will prove to be successful even in the negative conditions. The individual thus stands to gain in either situation.

Leary and Shepperd (1986) described self-handicapping as follows: Individuals posit obstacles to externalize the reasons for possibly unfavorable outcomes when they experience uncertainty about the result of their future performances. Tice (1991) described self-handicapping as a behavior pattern that the individual exhibits to 
protect or increase the feeling of self-esteem when he/she faces a situation that threatens his/her individuality.

Burger (2006) and Gerrig and Zimbardo (2012) related the self-handicapping concept to self-esteem. They described self-esteem as an individual's evaluation of selfhood and as a relatively determined and global measurement of the actual self of the individual. They describe self-handicapping as a process in which individuals develop explanations and behavioral responses in a failure expectation situation for minimizing the possibility to be regarded as the cause of failure and skill deficiencies. Individuals with low self-esteem can resort to a self-handicapping strategy. For example, they exhibit such behaviors as not studying for an exam, and they turn up the music while studying for an attention demanding lesson, thus intentionally decreasing the chances of being successful in a task. This is clearly self-handicapping behavior. These actions decrease the success of the individual. However, a "valid" excuse simultaneously emerges to explain the generated failure.

Self-handicapping emerges in various ways. It can be behavioral (waiting until the very last minute to perform a task) or verbal (saying that the health problems have affected the performance) (Leary \& Shepperd, 1986). Behavioral strategies generate a far greater risk of failure than do verbal strategies (Hirt, Deppe, \& Gordon, 1991). Self-handicapping affects the performance in the end (Steel, P., Brothen, T., \& Wambach, C. 2001; Gadbois \& Sturgeon, 2011). Individuals posit an excuse before the tasks, or in advance of the performance at that point. They may also make informed explanations for their behaviors (Urdan \& Midgley, 2001). Self-handicapping is much related to academic performance and to the learning types of students.

A positive correlation was determined between self-handicapping and negative variables such as depression and anxiety (Leondari \& Gonida 2007), a low feeling of self-determination and low self-esteem (Thomas \& Gadboisn 2007; Tice 1991; Rhodewalt \& Hill (1995), perfectionism (Kearns, Forbes, \& Gardiner, 2007), low performance tendencies (Leondari \& Gonida, 2007; Brown \& Kimble, 2009), low academic success (Rhodewalt \& Hill 1995), the external locus of control (Trice \& Milton 1987; Steel, Brothen \& Wambach 2001; Akın, 2012) and academic procrastination (Meyer, 2000). Chorba, Was and Isaacson (2012) investigated the relationship between ego identity development and academic success and found low rate of possibility to adopt self-handicapping skills in an academic environment for adolescences and young adults developing sense of academic identity. Rhodewalt and Hill (1995) investigated whether self-handicapping served to protect self-esteem or not in their experimental study. At the beginning of the term, they evaluated the undergraduates in terms of attribution types and personal differences in self-evaluation. Before the first exam, they allowed the students to express the factors that could handicap their performances in the exam. As a result, a relationship between self-handicapping and gender was determined. Male students stated that they were handicapped before the exam by their high levels of self-handicapping and after their poor performances in the exam, and receiving feedback, they attributed the failure to external reasons. The relationship between a self-handicapping tendency and posing excuses/obstacles and the performance attributes for the female students was lower when compared with that of the male students.

As is seen, the self-handicapping concept emerges as a personality variable in terms of personal differences in teaching environments. Its importance has been recognized in a short period of time. The academic self-handicapping concept means that the student uses various strategies to justify his/her academic failures, and by these means, blurs the relationship between academic performance and their personality/attributes (Abaci and Akın, 2011). For instance, when some students face the possibility of failure, they exhibit such behaviors as decreasing their effort, sparing less time for study or postponing study. So, they attribute their academic failures more to these behaviors than to their own skills (Cavendish, 2004).

In general, research has indicated that the academic self-handicapping tendency is related to perceived class targets and student motivation, coping strategies, qualities resulted from performance, time spared on study and ultimately academic performance (Thomas \& Gadbois, 2007; Abacı and Akın, 2011; Akın, Abacı and Akın, 2011). These variables are also related to how the students describe themselves as learners. According to the findings of the studies on the results of self-handicapping behavior, individuals who handicap themselves have low levels of academic success. They use nonfunctional coping strategies. The researchers also concluded that these individuals were perceived to be more negative in terms of their personality characteristics (Hirt, McCrea, \& Kimble, 2000).

Hirt and Kimble (2005) investigated the effect of self-focusing on the behavioral self-handicapping tendencies of the students. The students were asked to make self-evaluations and to interpret their performances when they faced a challenging assessment (an upcoming and difficult exam). The results showed that male participants practiced less when they focused on themselves and they exhibited self-handicapping behaviors. However, self-focusing did not result in self-handicapping in the female participants. 
Covington (1992) played an essential role in this issue with his studies exposing self-handicapping behavior in the school environment. Covington (1992) asserted that the desire of protecting self-esteem was the main cause of self-handicapping. The efforts made by the individual to not appear stupid and clumsy enabled them to distract other individuals from their own failures and inadequate performance. Covington (1992) mentioned students who were busy with too many activities and they put this forward as a reason for their inadequate performances. According to Covington (1992), self-handicapping is the situation where an individual accepts his/her minor inadequacy (experiencing test anxiety) in order to conceal his/her different and major inadequacy, one that is perceived as his/her deficiency by others.

Within educational environments, academic procrastination is one of the concepts that can be described as a personal difference. Academic procrastination is described as "to delay making a decision or the performance of a task, a behavioral tendency towards procrastination or a personality characteristic" (Milgram, Mey-Tal and Levison, 1998). More specifically, procrastination tendency can be described as the delay in performing an important task that the individual had previously decided to perform, and has the capacity for that task; but, the individual postpones this task with no good reason. This complex fact has four distinct types as 1-general procrastination, 2- Academic procrastination, 3- Procrastinating decision making 4- Neurotic procrastination 4Obsessed or nonfunctional procrastination (Grecco, 1984).

Procrastination behavior is widely seen within the academic world as well as in the general population. Understanding the causes and results of procrastination is important (Balkış and Duru, 2007). Özer and Altun (2011) investigated the reasons behind the procrastination of undergraduates according gender, success at school, hope, perfectionism, external supervision, self-esteem, responsibility, academic self-sufficiency and achievement tendencies. As a result, they found that the students who tended to avoid meeting performance aims and who had a low sense of responsibility delayed on their academic studies through laziness and a fear of failure. Academic procrastination has some negative effects on the academic performances of the students in the form of withdrawal from their courses and the attainment of a low academic average (Semb, Glick and Spencer, 1979). In addition, the number of students exhibiting procrastination behavior is quite considerable (Bishop Gallagher and Cohen, 2000).

Studies conducted on the causes of academic procrastination seem to especially focus on perfectionism (Sadler and Buley, 1999), and personality characteristics (Anderson, 2001; Milgram and Tenne, 2000), the repulsiveness of the task, protest against being controlled, and an aversion to risk-taking (Uzun and Ferrari, 2011). A range of studies have been conducted to investigate personality variables related to procrastination (leaving things till the very last minute). Johnson and Bloom (1995) stated that the individuals who exhibited the behavior of procrastination (leaving tasks to the very last minute) showed high levels of neuroticism and low levels of conscientiousness (cited by Lonergan, 1998). Similarly, the relationship between the general and academic procrastination of undergraduates and self-esteem, perfectionist personality characteristics and academic success has been reported in previous studies (Çakıc1, 2003). In these studies it was also concluded that the academic procrastination of the undergraduates was an important predictor of the personal perfectionism of the individual, and the perfectionism related to the expectations of others of the individual.

In another study of academic procrastination, a significantly positive correlation was determined between academic procrastination and a negative attitude towards studying and learning, ineffective time management and difficulty in concentration (Balkış et al. 2006). Kağan (2009) concluded that academic motivation, anxiety, time management, general procrastination behavior and irrational beliefs predicted academic procrastination behavior.

Self-handicapping and especially procrastination are related to high levels of depression, anxiety and low levels of self-esteem (Lay \& Silverman, 1996; T. Martin, Flett, Hewitt, Krames \& Szanto, 1996; Saddler \& Sacks, 1993). Meyer (2000) researched the use of academic procrastination as a self-handicapping strategy and stated that there was a positive correlation between them.

One of the concepts related to self-handicapping is the locus of control. The results of a study showed that the internal and external locus of control were in relation with self-handicapping at varying levels (Akin, 2012). It was concluded that the locus of control was also in relation with performance and control (Weiner, 1979; Trice \& Milton, 1987; Simek \& Grum, 2011). Ferrari, Parker \& Ware (1992) determined a strong relationship between procrastination and the academic locus of control. Beswick, Rothblum and Mann (1988) determined a mid-level relationship between procrastination and the locus of control.

Deniz, Traş and Aydoğan (2007) investigated the effect of the emotional intelligence skills of undergraduates on academic procrastination and the locus of control. As a result of the research, it was concluded that compatibility 
and coping with stress (sub-dimensions of emotional intelligence skills) predicted the scores of the academic procrastination of the students. Negatively significant relationships were determined between the scores of emotional intelligence skills and academic procrastination and the locus of control.

When the above mentioned studies were evaluated as a whole it was seen that a better comprehension of nature of self-handicapping behavior is needed. Self-handicapping behavior is widespread and a common phenomenon among students. With this aim, the relationship of self-handicapping to academic procrastination, the locus of control and academic success is here investigated. Many studies in the body of literature concerning the above mentioned variables have been conducted abroad. However, it is obvious that this issue has not been given enough attention in Turkey. So, the present study is quite important in terms of being the first in Turkey to comprehend the relationship between academic procrastination, the locus of control and academic success, especially in teaching environments.

In the present study, an attempt was made to answer the following questions:

1) Is there a relationship between self-handicapping, the locus of control and academic success?

2) Do academic procrastination, the locus of control and academic success predict self-handicapping?

\section{Method}

The research is a descriptive survey model study. Existing state is described and interaction of the variables was investigated accordingly.

\subsection{Participants}

The participants consisted of 263 volunteers aged between 19 and 28 years (mean age: 22.02) who attend Uludağ University Education Faculty in 2011-2012 academic year. Each data was seperately collected from each class and 20 minutes were given to each student for completing each scale. To determine the sample, "proportional cluster sampling approach" (Karasar, 1998) were used. While $22.1 \%$ of the students were in $2^{\text {nd }}$ grade, $36.9 \%$ of them were in $3^{\text {rd }}$ grade, and $41.1 \%$ of them were in $4^{\text {th }}$ grade. Of them, 181 were females and 82 were males. Thirty and a half percent of the students were graduated from Anatolian High School, $28 \%$ of them were graduated from General High School, $8 \%$ of them were graduated from Vocational Technical High School, and $6.5 \%$ of them were graduated from Imam Hatip High School.

\subsection{Research Instruments}

In the current study, "Self-Handicapping Scale", "Academic Procrastinating Scale", "Rotter Control Scale" and "Personal Information Sheet were used to gather the data.

\subsubsection{Self-Handicapping Scale (SHS)}

The validity and reliability of Turkish version of the SHS that developed by Jones and Rhodewal (1982) was investigated by Akın (2012a). In linguistic equivalence studies, the Pearson correlation coefficient between the Turkish version and original form of SHS was found to be .91 for entire scale. This value indicates a strong positive relationship between Turkish version and original form of SHS. The explanatory factor analysis yielded a one-factor solution. The one-factor solution accounted for $32 \%$ of variance of the total variance. Generally, a factor solution which accounts for more than $30 \%$ of the total variance can be considered adequate (Büyüköztürk, 2004). Factor loadings of scale ranked from .34 to .69. Considering that the absolute value of factor loading after varimax rotation must be greater than 0.3 (Büyüköztürk, 2004), all factor loadings are satisfactory. Corrected item-total correlations ranged from .30 to .63., which are very good, as the general recommendation (Büyüköztürk, 2004) is that corrected-item total correlations should be 0.3 and higher. Results of confirmatory factor analysis indicated that the unidimensional model was well fit (RMSEA=.037, NFI $=.98, \mathrm{CFI}=.99, \mathrm{IFI}=.99$, $\mathrm{RFI}=.97, \mathrm{GFI}=.97, \mathrm{AGFI}=.94)$. Internal consistency reliability coefficient of SHS was found .90 and test-retest reliability coefficient was found .94., which are satisfactory, as the general recommendation (Büyüköztürk, 2004) is that reliability coefficients should be at least 0.80 or higher in order for a psychological measurement to be considered reliable. SHS consists of 25 items and participants indicated the degree to which they agree with each item on the SHS using a 6-point-Likert type scale. The possible range of scores is from 25 to 125 . Higher scores means higher verbal and behavioral self-handicapping tendency.

\subsubsection{Academic Procrastination Scale}

"Academic Procrastination Scale" that was developed to determine students' academic procrastination behaviors by Çakıcı (2003) was used. Academic Procrastination Scale is an 19 item measure containing 12 positively worded items and 7 negatively worded items, which include the tasks that students are responsible in education life. The responses given to the phrases of the scale are ranked with five point likert scale: "never reflects me", 
slightly reflects me", "somewhat reflects me", "generally reflects me", and "always reflects me". Internal consistency reliability coefficients were found .92 for Academic Procrastination Scale, .89 for the first scale, and .84 for the second scale, and a seventeen-days test-retest reliabilities were $0.89,0.80$ for the first factor, and 0.82 for the second factor (Çakıc1, 2003), which were quite high, as the general recommendation (Büyüköztürk, 2004 ) is that reliability coefficients should be at least 0.80 or higher.

\subsubsection{Locus of Control Scale}

In the study, "Internal-External Locus of Control Scale", which was developed by Rotter and adapted to Turkish by Dağ (1991) was used to determine students' locus of control. Rotter Locus of Control Scale consists of 29 items, first 6 items were filling material and scores ranked between $0-23$ can be obtained. While higher scores show that individual is external controlled, lower scores show that individual is internal controlled. Cronbach's alpha coefficient for the entire scale was 0.71 indicating relatively low reliability.

\subsubsection{Personal Information Sheet}

In this form, there were questions related to their study departments, gender, general grade-point averages, and grades of the students.

\section{Data Analysis}

The data obtained from the research were uploaded to electronic environment and analyzed using SPSS for Windows version 16. The data were tested with Pearson product-moment correlation and multiple regression analysis.

\section{Results}

Correlation coefficients are calculated in order to determine the relations between the variables that discussed in the research. Correlation values are presented in Table 1.

Table 1. Mean and Standard deviations and inter-correlations of the variables

\begin{tabular}{lllll}
\hline Variables & Academic Success & $\begin{array}{l}\text { Academic } \\
\text { Procrastination }\end{array}$ & Locus of Control & Self-Handicapping \\
\hline Academic Success & & & & \\
Academic & -.12 & & & \\
Procrastination & & $.16^{* *}$ & $.26^{* *}$ & \\
Locus of Control & $-.14^{*}$ & $.41^{* *}$ & 10.75 & 80.18 \\
Self-Handicapping & $-.18^{* *}$ & 57.24 & 3.76 & 11.81 \\
Mean & 2.57 & 7.22 & & \\
Standart deviation & .56 & & & \\
$* * \mathrm{p}<.01, * \mathrm{p}<.05$ & & & & \\
\hline
\end{tabular}

As it is seen in Table 1, self-handicapping was moderate positively correlated with academic procrastination $(\mathrm{r}=0.42, p<.01)$, and was weak positively correlated with locus of control $(\mathrm{r}=0.26, p<.01)$. A weak positive and significant relation was found between academic procrastination and locus of control $(\mathrm{r}=0.17, p<.01)$. Self-handicapping showed weak negative correlations with academic success $(\mathrm{r}=-0.18, p<.01)$, and self- locus of control $(\mathrm{r}=-0.14, p<.05)$. There is no significant relation between academic procrastination and academic success.

It is shown in Table 1 that self-handicapping levels of university students are slightly higher than the mean (Mean=80.18; $\mathrm{SD}=11.81$ ). According to the academic procrastinating scores, it was found that students display academic procrastination behavior in avarage level (Mean= 57.24, $\mathrm{SD}=7.22$ ). According to locus of control scores, students generally have internal locus of control (Mean=10.75, SD =3.76). Finally, it can be said that the students are partially successful in terms of academic success (Mean=2.75, $\mathrm{SD}=.56$ ).

Multiple regression analysis was done to test the predictive strength of academic procrastination, locus of control, and academic success. The results of multiple regression were presented in Table 2. 
Table 2. Results of multiple regression analysis about the prediction of academic procrastination and academic success for self-handicapping

\begin{tabular}{llllll}
\hline Variables & $B$ & Standard Error & $\beta$ & $\mathrm{t}$ & $\mathrm{p}$ \\
\hline Step 1 & & & & & \\
Academic Procrastination & .68 & .09 & .416 & 7.38 & .000 \\
\hline Step 2 & & & & & \\
Academic Procrastination & .625 & .09 & .382 & 6.85 & .000 \\
Locus of Control & .632 & .176 & .201 & 3.59 & .000 \\
\hline Step 3 & & & & & \\
Academic Procrastination & .607 & .091 & .371 & 6.65 & .000 \\
Locus of Control & .588 & .176 & .187 & 3.34 & .001 \\
Academic Success & -2.34 & 1.16 & -.112 & -2.017 & .045 \\
\hline
\end{tabular}

In the first step of the regression analysis, it was seen that academic procrastination explains $17 \%$ of handicapping $\left(R^{2}=.17\right.$, adjusted $\left.R^{2}=.17, F(1,261)=54.49, p<.05\right)$. In the second step, it was seen that locus of control also got in the regression equality and it contributed to explained-variance in $4 \%$ level $\left(R^{2}=.21, \Delta R^{2}=.04\right.$, adjusted $\left.R^{2}=.21, F(1,260)=12.94, p<.05\right)$. In the third step, academic success got in regression equality and and only $1 \%$ of it contributed to explained-variance $\left(R^{2}=.22, \Delta R^{2}=.1\right.$, adjusted $\left.R^{2}=.22, F(1,259)=4.067, p<.05\right)$. According to the standardized coefficients, the most relatively important variable is academic procrastination for the prediction of self-handicapping $(\beta=.371)$.

\section{Discussion}

The aim of the present study is to investigate the self-handicapping behaviors of undergraduates in terms of academic procrastination, the locus of control and academic success.

The analyses showed that there was a negative correlation between self-handicapping and academic success. This finding supports previous findings that relate the self-handicapping behaviors of students to low levels of academic success (Akın, Abac1, \& Akın, 2010; Urdan \& Midgley, 2001). It is necessary for students to be aware of their given responsibilities, to perform academic tasks on time, and to develop the habits and skills of studying systematically to be successful academically. The skills of determining aims and priorities are also necessary to be successful. When the findings of the present study are evaluated under the light of the findings of the aforementioned studies, it is possible to say that the academic performance of students with high levels of self-handicapping behaviors, due to their having difficulty in time management, not showing enough interest in the school lessons, exhibiting high levels of self-handicapping behaviors and not being decisive in performing tasks are decreasing.

The results which included significantly positive correlations between self-handicapping and the locus of control and academic procrastination of undergraduates were in parallel with the results in the literature (Flett, Hewitt \& Martin, 1995; Sadler \& Buley, 1999; Steel, Brothen, T., \& Wambach, 2001). According to these results, students with high levels of self-handicapping characteristics exhibit much academic procrastination behavior. It was determined that these students also had characteristics with external locus of control. Students with high levels of self-handicapping behaviors stated that the conditions should be better and that emotional factors prevented their concentration. These statements were in parallel with the characteristics of individuals with external locus of control which featured the importance of external factors. It is possible to say that students who exhibit academic failure as a result of self-handicapping behaviors relate this with external factors or use the effect of external factors as an excuse in the self-handicapping explanations. In another words, this finding explains very well the situation of the students who relate their academic failure with teacher strategies, class environments, classroom equipment, the lack of technical equipment or opportunities to use it in the university instead of relating the failure to self-handicapping behaviors or academic procrastination.

The academic self-handicapping concept means that the student uses various strategies to justify his/her academic failures and in this way he/she makes indistinct the relationship between academic performance and his/her personality attributes (Akı, Abacı \& Akın, 2010). According to this, when some students face the possibility of failure, they exhibit behaviors such as decreasing their effort, sparing less time for study or 
postponing study. The aim of these behaviors is to attribute their possible academic failure to these behaviors more than to their skills and abilities. In other words, these students believe that failure resulting from laziness is better than failure resulting from stupidity, therefore can easily handicap themselves (Cavendish, 2004). So, the need for a focus on what the students do to handicap themselves, in addition to any cognitive inadequacies that result in academic failure, at nearly all stages of education, emerges.

It was concluded in the study that academic procrastination, the locus of control and academic success significantly predicted self-handicapping behavior. These variables explained the $22 \%$ of the variance related to self-handicapping behavior. This result shows that the locus of control, academic procrastination and academic success are important factors in explaining the self-handicapping behaviors of undergraduates. It was concluded that the most important predictor of self-handicapping was academic procrastination. Beck, Koons and Milgrim (2000) investigated the predictors of academic procrastination and their effects on exam performance in their study. They concluded that students with a high tendency towards self-handicapping and procrastination spent less time on preparation for the exam; they delayed preparation for the exam and got low marks. In the same study, it was concluded that the effects of high levels of self-handicapping and high levels of self-esteem together caused procrastination over preparation for the exam. As a result, a high level of correlation was determined between academic procrastination and self-handicapping. These findings show that as a result of academic procrastination and self-handicapping, undergraduates study for just a few hours for an exam the night before the exam takes place rather than studying systematically and regularly, and they demanded easy questions and test-type intensive exams.

Self-doubt triggers a desire for self-protection and leads to self-handicapping behavior (Urdan \& Midgley, 2001). Hendrix and Hirt (2009) conducted a study in which they determined that self-handicapping was a kind of self-protection mechanism. They attempted to show that students were motivated by the need for protection against anxiety related to the possibility of failure. In addition, they investigated the role of "regulatory compatibility" in the use of self-handicapping. The researchers concluded that students could increase the use of self-handicapping in the regulatory compatibility required cases. The gestalt approach expresses self-handicapping as a kind of resistance. This approach points to the situations in which the individual procrastinates or does not even start in spite of action being necessary. According to the gestalt approach, resistance is a kind of "creative compatibility" which the individual exhibits for self-protection from the anxiety provoked by a new situation (Daş, 2006). It is possible to see the same concept in the "regulatory compatibility" concept which is explored in the study of Hendrix and Hirt (2009). So, it is possible to say that the individual is in a kind of self-protection situation in respect of nearly all kinds of handicapping. In this concept, it is necessary to guide the students to quit "regulatory compatibility" or "creative compatibility" especially in teaching environments. It is also necessary to seek appropriate conditions of cooperation for the new creative compatibilities.

As a result, when the relationships between academic procrastination tendencies, the external locus of control, academic success and self-handicapping behavior are examined, it can be concluded that conducting awareness studies in relation to the self-handicapping behaviors of students can decrease the level of academic procrastination. These studies can also be effective in decreasing the negative effects of the academic procrastination tendency on academic success. Psychological counselors and educators should use compatible psycho-education programs. They could also conduct studies related to how and where the self-handicapping behaviors of the students emerge using the above mentioned programs. They can also lead students to take responsibility for their success via directives that enable the students to have more internal locus of control.

Self-handicapping behavior can be described as a personality variable within the personal differences concepts. In the emergence of self-handicapping behavior, the relationships between the academic procrastination tendency, the locus of control and academic success can be tested via a structural equality model. Studies could be conducted to determine the variables that mediate academic success via self-handicapping. Studies related to the presence of other variables that cause self-handicapping behaviors, via experimental studies, could also be conducted.

\section{References}

Abacı, R., \& Akın, A. (2011). Kendini sabotaj: İnsanoğlunun sinırlı doğasının bir sonucu. Ankara: Pegem Yayınları.

Akın, A., Abacı, R., \& Akın, Ü. (2011). Self-handicapping: A Conceptual Analysis, International Online Journal of Educational Sciences, 3(3), 1155-1168. Retrieved from http://www.iojes.net//userfiles/Article/IOJES_462.pdf 
Akın, A. (2012a). Kendini Sabotaj Ölçeği: Geçerlik ve güvenirlik çalışması. Eğitim ve Bilim, 3(164), 176-187. Retrieved from http://egitimvebilim.ted.org.tr/index.php/EB/article/view/717/372

Akın, A. (2012b). Academic locus of control and self-handicapping. Procedia-Social and Behavioral Sciences, 30, 812-816. http://dx.doi.org/10.1016/j.sbspro.2011.10.157

Anderson, E. M. (2001). The relationships among task characteristics, self-regulation and procrastination. Educational Psychology, 62(5), 2530. Retrieved from http://psycnet.apa.org/psycinfo/2001-95022-204

Balkıs, M., \& Duru, E. (2007). Erteleme davranışı ile ilişkili karakteristik ve boyutların psikolojik danışma ve rehberlik çerçevesinde incelenmesi. Kuram ve Uygulamada Eğitim Bilimleri, 7(1), 349-385. Retrieved from $\mathrm{http}: / /$ www.edam.com.tr/kuyeb/tr/onceki_sayilar.asp?act=detay\&ID $=26$

Balkıs, M., Duru, E., Buluş, M., \& Duru, S. (2006). Üniversite öğrencilerinde akademik erteleme eğiliminin çeşitli değişkenler açısından incelenmesi. Ege Eğitim Dergisi, 7(2), 57-73.

Beck, B. L., Koons, S. R., \& Milgram, D. L. (2000). Correlates and consequences of behavioral procrastination: The effects of academic procrastination, self-consciousness, self-esteem and self-handicapping. Procrastination: Current Issues and New Directions.[Special Issue]: Journal of Social Behavior and Personality, 15(5), 3-13. Retrieved from http://psycnet.apa.org/psycinfo/2002-10572-001

Berglas, S., \& Jones, E. E. (1978). Drug choice as a self-handicapping strategy in response to noncontingent success. Journal of Personality and Social Psychology, 36(4), 405-417. http://dx.doi.org/10.1037/0022-3514.36.4.405

Beswick, G., Rothblum, E. D., \& Mann, L. (1988). Psychological antecedents of student procrastination. Australian Psychologist, 23(2), 207-217. http://dx.doi.org/10.1080/00050068808255605

Büyüköztürk, Ş. (2004). Veri analizi el kitabı. Ankara: Pegem A Yayıncılık.

Brown, C. M., \& Kimble, C. E. (2009). Personal, interpersonal, and situational influences on behavioral $\begin{array}{llll}\text { self-handicapping. The Journal of Social Psychology, 149(6), 609-626. } & \text { The }\end{array}$ http://dx.doi.org/10.1080/00224540903344971

Burger, J., M. (2006). Kişilik. İ. D. E. Sarıŏglu (Çev.). İstanbul: Kaknüs Yayınları.

Cavendish, S. (2005). Self-efficacy and use of self-regulated learning strategies and academic self-handicapping among students with learning disabilities. Doctoral Dissertation, Wayne State University. Retrieved from $\mathrm{http}: / /$ search.proquest.com/docview/305385643? accountid=8319

Chorba, K., Was, C. A., \& Isaacson, R. M. (2012). Individual differences in academic identity and self-handicapping in undergraduate college students. Individual Differences Research, 10(2), 60-68. Retrieved from http://ehis.ebscohost.com/ehost/pdfviewer/pdfviewer?sid=08e1d7cd-e1c7-4821-8ef3 01282e1c4a8a\%40sessionmgr11\&vid=8\&hid $=115$.

Covington, M. V. (1992). Making the grade: A self-worth perspective on motivation, and school reform. New York, NY: Cambridge University Press.

Çakıcı, Ç. D. (2003). Lise ve üniversite öğrencilerinde genel erteleme ve akademik erteleme davranışının incelenmesi. Yayınlanmamış Yüksek Lisans Tezi. Ankara Üniversitesi, Eğitim Bilimleri Enstitüsü, Ankara.

Dağ, İ. (1991). Rotter'in İç-Dış Kontrol Odağı Ölçeği (RİDKOÖ)'nin üniversite öğrencileri için güvenirliği ve geçerliliği. Psikoloji Dergisi, 26, 10-16.

Daş, C. (2006). Bütünleşmek ve büyümek. Ankara: Hekimler Yayın Birliği.

Deniz, M. E., Traş, Z., \& Aydoğan, D. (2009). An investigation of academic procrastination, locus of control, and emotional intelligence. Educational Sciences: Theory and Practice, 9(2), 623-632. Retrieved from http://www.eric.ed.gov/PDFS/EJ847770.pdf

Ferrari, J., Parker, J., \& Ware, C. (1992). Academic procrastination: Personality correlates with Myers-Briggs Types, self-efficacy, and academic locus of control. Journal of Social Behavior and Personality, 7, 495-502. Retrieved from http://psycnet.apa.org/psycinfo/1993-15437-001

Flett, G. L., Hewitt, P. L., \& Martin, T. R. (1995). Dimensions of perfectionism and procrastination. In J. R. Ferrari, J. L. Johnson \& W. G. McCown (Eds), Procrastination and task avoidance: Theory, research and treatment (pp.113-136). New York: Plenum.

Gadbois, S. A., \& Sturgeon, R. D. (2011). Academic self-handicapping: Relationships with learning specific and general self-perceptions and academic performance over time. British Journal of Educational Psychology, 


\section{1, 207-222. http://dx.doi.org/10.1348/000709910X522186}

Gerrig, R. J., \& Zimbardo, P. G. (2012). Psikolojiye giriş: Psikoloji ve yaşam (19. Baskı). Ankara: Nobel Yayınları.

Grecco, P. R. (1984). A cognitive-behavioral assessment of problematic academic procrastination: development of a procrastination self- statement inventory. Unpublished PHD, California School of Professional Psychology: Fresno.

Hendrix, K. S., \& Hirt, E. R. (2009). Stressed out over possible failure: The role of regulatory fit on claimed self-handicapping. Journal of Experimental Social Psychology, 45, 51-59. http://dx.doi.org/10.1016/j.jesp.2008.08.016

Hirt, E. R., Deppe, R. K., \& Gordon, L. J. (1991). Self-reported versus behavioral self-handicapping: Empirical evidence for a theoretical distinction. Journal of Personality and Social Psychology, 61(6), 981-991. http://dx.doi.org/10.1037/0022-3514.61.6.981

Hirt, E. R., McCrea, S. M., \& Kimble, C. E. (2000). Public self-focus and sex differences in behavioral self-handicapping: Does increasing self-threat still make it "just a man's game?" Personality and Social Psychology Bulletin, 26(9), 1131-1141. http://dx.doi.org/10.1177/01461672002611009

Hirt, E. R., \& Kimble, C. E. (2005). Self-focus, gender, and habitual self handicapping: Do they make a difference in behavioral self-handicapping? Social Behavior and Personality, 33(1), 43-56. http://dx.doi.org/10.2224/sbp.2005.33.1.43

Jones, E. E., \& Rhodewalt, F. (1982). The Self-Handicapping Scale. (Available from Frederick Rhodewalt, Department of Psychology,University of Utah, Salt Lake City, UT 84112).

Kağan, M. (2009). Üniversite öğrencilerinde akademik erteleme davranışını açıklayan değişkenlerin belirlenmesi. Ankara Üniversitesi Ĕgitim Bilimleri Fakültesi Dergisi, 42(2), 113-128. Retrieved from http://dergiler.ankara.edu.tr/dergiler/40/1223/13976.pdf

Karasar, N. (1998). Bilimsel Araştırma Yöntemi (3. Baskı). Ankara: Nobel Yayın.

Kearns, H., Forbes, A., \& Gardiner, M. (2007). A cognitive behavioural coaching intervention for the treatment of perfectionism and self-handicapping in a nonclinical population. Behaviour Change, 24(3), 157-172. http://dx.doi.org/10.1375/bech.24.3.157

Kuzgun, Y., \& ve Deryakulu, D. (2004). Bireysel Farklılıklar ve Eğitime Yansımaları. In Y. Kuzgun, D. Deryakulu (Ed.), Eğitimde bireysel farkllllklar. Ankara: Nobel Yay.

Lay, C., \& Silverman, S. (1996). Trait procrastination, anxiety, and dilatory behavior. Personality and Individual Differences, 21, 61-67. Retrieved from http://www.sciencedirect.com/science/article/pii/0191886996000384

Leary, M. R., \& Shepperd, J. A. (1986). Behavioral self-handicaps versus self-reported selfhandicaps: A conceptual note. Journal of Personality and Social Psychology, 51, 1265-1268. http://dx.doi.org/10.1037/0022-3514.51.6.1265

Leondari, A., \& Gonida, E. (2007). Predicting academic self-handicapping in different age groups: The role of personal achievement goals and social goals. British Journal of Educational Psychology, 77, 595-611. http://dx.doi.org/10.1348/000709906X128396

Lonergan, J. (1998). Locus of control as moderator of the relationship between job characteristics and procrastination at work. University of St. Thomas. BA: California.

Meyer, C. L. (2000). Academic procrastination and self-handicapping: Gender differences in response to non-contingent feedback. Procrastination: Current Issues and New Directions [Special Issue]: Journal of Social Behavior and Personality, 15(5), 87-102. Retrieved from https://vpn.uludag.edu.tr/http/0/ehis.ebscohost.com/ehost/pdfviewer/pdfviewer?vid=3\&hid=109\&sid=89d8 c1e1-c091-4797-adda-24bf578badbc\%40sessionmgr114

Milgram, N., Mey-Tal, G., \& Levison, Y. (1998). Procrastination, generalized or specific, in college students and their parents. Personality and Individual Differences, 25(2), 297-316. http://dx.doi.org/10.1016/S01918869(98)00044-0

Milgram,N., \& Tenne, R. (2000). Personality correlates of decisional and task avoidant procrastination. European Journal of Personality, 141-156. http://dx.doi.org/doi:10.1002/(SICI)1099-0984(200003/04)14:2<141::AID-PER369>3.0.CO;2-V 
Özer, A., \& Altun, E. (2011). The Reasons for academic procrastination among university students. Mehmet Akif Ersoy Üniversitesi Eğitim Fakültesi Dergisi, 11(21), 45-72. Retrieved from http://edergi.mehmetakif.edu.tr/index.php/efd/article/view/303/241

Rhodewalt, F., \& Hill, K. (1995). Self-handicapping in the classroom: The effects of claimed self-handicaps on responses to academic failure. Basic and Applied Social Psychology, 16(4), 397-416. http://dx.doi.org/10.1207/s15324834basp1604_1

Rothblum, E. D., Solomon, L. J., \& Murakami, J. (1986). Affective, cognitive, and behavioral differences between high and low procrastinatiors. Journal of Counseling Psychology, 33, 387-394. http://dx.doi.org/10.1037/0022-0167.33.4.387

Sadler, C. D., \& Buley, J. (1999). Predictors of academic procrastination in college students. Psychological Reports, 84, 686-688. http://dx.doi.org/10.2466/pr0.1999.84.2.686

Semb, G., Glick, D. M., \& Spencer, R. E. (1979). Student withdrawals and delayed work patterns in self-paced psychology courses. Teaching of Psychology, 6(1), 23-25. http://dx.doi.org/10.207/s15328023top0601_8

Šimek, D., \& Grum, D. K. (2011). Competitiveness and motivation for education in self-handicapping. Studia Psychologica, 53(1), 83-96. $\quad$ Retrieved from http://boun.summon.serialssolutions.com/search?s.q=\%C5\%A0imek\%2C+D.+and+Grum\%2C+D.+K.+\%2 $82011 \% 29$

Steel, P., Brothen, T., \& Wambach, C. (2001). Procrastination and personality, performance, and mood. Personality and Individual Differences, 30(1), 95-106. http://dx.doi.org/10.1016/S0191-8869(00)00013-1.

Tice, D. M. (1991). Esteem protection or enhancement? Self-handicapping motives and attributions differ by trait self-esteem. Journal of Personality and Social Psychology, 60(5), 711-725. http://dx.doi.org/10.1037/0022-3514.60.5.711

Thomas, C. R., \& Gadbois, S. A. (2007). Academic self-handicapping: The role of self-concept clarity and students' learning strategies. British Journal of Educational Psychology, 77, 101-119. http://dx.doi.org/10.1348/000709905X79644

Trice, A., \& Milton, C. (1987). Locus of control as a predictor of procrastination among adults in correspondence course. Perceptual and Motor Skills, 65, 1002. http://dx.doi.org/doi: 10.2466/pms.1987.65.3.1002

Urdan, T., \& Midgley, C. (2001). Academic self-handicapping: What we know, what more there is to learn? Educational Psychology Review, 13(2), 115-138. http://dx.doi.org/10.1023/A:1009061303214

Uzun, Ö. B., \& Ferrari, J. R. (2011). Gender orientation and academic procrastination: Exploring Turkish high school students. Individual Differences Research, 9(1), 33-40.

Weiner, B. (1979). A theory of motivation for some classroom experiences. Journal of Educational Psychology, 71, 3-25. http://dx.doi.org/10.1037/0022-0663.71.1.3 